\title{
Ancient History of Arabian Peninsula and Semitic Arab Tribes
}

\author{
Salahuddin Mohd. Shamsuddin
}

Faculty of Arabic Language, Sultan Sharif Ali Islamic University, Brunei Darussalam

Siti Sara Binti Hj. Ahmad

Dean: Faculty of Arabic Language, Sultan Sharif Ali Islamic University, Brunei Darussalam

\begin{abstract}
In this article we introduced first the ancient history of Arabian Peninsula, and pre-Islamic era and then we focused a spot light on the people of Arabian Peninsula, highlighting the four waves of migration of Semitic Arabs from the southern to northern Arabian Peninsula, then we mentioned the situation of Northern Arabs and their tribal fanaticism, then we differentiated between Qahtaniyya and Adnaniyya Arab tribes including their three Classes: Destroyed Arab, Original Arab and Arabized Arab. We also explained the tribal system in the pre-Islamic era, indicating the status of four pillars of the tribal system:

1. Integration and alliance among the tribes

2. Tribal Senate or Parliament

3. Tribes and sovereignty over the tribes

4. Members of the tribes and their duties towards their tribal society

In the end we described the master of Arab tribe who was the brightest person had a long experience and often had inherited his sovereignty from his fathers to achieve a high status, but it does not mean that he had a broad sovereignty, as his sovereignty was symbolic. He had no rights except that he was obeyed and respected by everyone. We tried to mention all these points with some further details.
\end{abstract}

Keywords: 1. Arabian Peninsula, 2. Pre-Islamic Era, 3. Semitic Arabs, 4. Arab tribes, 5. Integration and Alliance 6. Master of Arab tribe.

\section{Introduction: Ancient History of Arabian Peninsula}

There is no doubt that the study of pre-Islamic era is very important, because it is that which can enable us to see the correct picture of the situation of the life of Arabs that was in pre-Islamic era, which is called by Islam the ignorance era, so before we study that era and that situation, it is better to shed some lights on the geography of Arabian Peninsula.

Arabian Peninsula is a spacious diameter, with an area of about one million square miles, or at most one million and three hundred thousand square miles, and it includes the southwestern region of Asia. It is called the peninsula, because the water surrounds it from three sides, from the south, west 
and east, bordering the Arabian Gulf and the Sea of Oman in the east, the Indian Ocean in the south, and the Red Sea in the west, and the Levant Valley is located in the north. Its northern border begins in Gaza, located on the eastern Mediterranean coast, passes by the Dead Sea and extends to eastern Jordan, then passes through Damascus, heading towards Euphrates and ends at Persian Gulf. Geologists believe that it was connected to the African continent in the depths of time. Then it separated from North Africa with the appearance of Red Sea. Thus became surrounded by the water except from the north, and from here it is named the peninsula or (Arabian Peninsula) as it is called by Arab people themselves. [1]

The ancient geographers of Greece and Romans divided it into three sections: 1. Rocky or Stony Arab Countries, 2. Desert Arab Countries, 3. Happy Arab Countries.

\subsection{Rocky or Stone Arab Country}

Stone Arab country consists of the island of Sinai, which extends from the borders of Palestine to Red Sea, and is surrounded by a flint of stone flanked by rocky sparsely populated areas. Arab geographers do not consider the stony Arab countries as a part of Arabian Peninsula, although the geographical and ethnographic make the stony Arab countries a part of the Arabian Peninsula.

\subsection{Desert Arab Countries}

The desert Arab countries are divided into three types as their nature:

\section{2. 1. The first}

It is the desert that called by the Arabs: (Desert of Samawah), it is located in the north between Kufa and the Levant, and it is a flat land has no stone, and there are only a few water wells and resources. It is located to the south of the (desert of Samawah), and Aga and Salma mountains. They are known also as mountains of Shammar, and they are from the western range of mountain Al-Surat. They tend to the direction of east and extend to the plains in the north of the city.

\section{2. 2. The second}

It is the desert that lies in the south, which is called: (the Empty Quarter). It is connected to the desert Samawah in the north and extends to the Arabian Gulf in the east. It is a large sandy desert dominated by the dryness and wilderness. There are trees and palm trees in a few parts of this area. There are no valleys have the water except a small number such as: Sarhan valley in the north, AlRamah valley and Al-Dawasir valley in the south, where some rains fall, so the valleys are filled with the water.

\section{2. 3. The third}

That desert created by volcanoes, it is "the heat means a land with black stones, grunt as if burned with fire" as mentioned by Yaqūt Al-Himawi. (The hottest lands) are so many in Arab countries, especially around Medina, and Yaqūt counted them in his book, The Glossary of Countries, about 19 hottest lands and well-known is: Tabuk, Harrat Salim, Harat Laili, Harat Autas, Harat Glas, and Harrat Waqim. [2]

\section{3. Happy Arab Countries}

The happy Arab countries include Najd, Hejaz, Yemen and Oman. Najd is located in the South of the Badia Al-Sham, and it includes the middle of the Arabian Peninsula between Al-Hejaz and Al-Ahsa with the region al-Yamamah or al-Arud, where the city was deserted, and separates Najd from the hills of Amman, the desert of the Empty Quarter. 
Shamsuddin, S. M., \& Ahmad, S. S. B. (2020). Ancient History of Arabian Peninsula and Semitic Arab Tribes. Advances in Social Sciences Research Journal, 7(5) $270-282$.

Hijaz is located in the south of the Sinai Island, and it runs along with the Red Sea from Ayila (Known by the name of Aqaba today) to Yemen. It was called Hejaz, because it separates between Tehama and Najd or between Tehama and al-Arud or between al-Yamama and al-Arud, and between Yemen and Najd.

Generally, Hijaz is a poor country with many valleys that are filled with the rainy water, and its climate is very hot, but it is mild in some cities such as Taif. Hijaz has a very big importance because of two major cities: Mecca and Medina, and it has received a great attention from the researchers, scholars and historians, because it is the cradle of Islam from which the new religion spread.

The countries of Yemen are located in the south of Hijaz, which is rich with its fertile lands since ancient times. There is agriculture that depends on the water collected from the monsoons, which is available in good drainage. The most famous cities of Yemen are Sana'a, Aden and Najran, and the eastern city Hadramout is located on the coast of the Indian Ocean. There are so many mountains and valleys. Zefar city is located in the east of Hadhramaut, which is famous for the spices and fragrant vegetables, especially frankincense.

Oman is located at the end of the southeast of Arabian Peninsula, which is sprawling, includes a large land with the palm trees and plantations. It is famous for the skill of its inhabitants in the navigation, so the commercial relations between India and East Arabia have been established regularly since a long time ago.

Some historians believe (that all the Semitic traditions indicate that the Arabian Peninsula is the first cradle for the Semites), as they came and settled and lived a common life there. Arabian Peninsula, especially its central parts were not desert and barren as we see them today, but were fertile and suitable for living, life and housing in ancient times, then they became dehydrated, obliterating their features and removing their civilization. It is also said that Najd is the first cradle in which the Semites were embraced, as it printed them with the indelible character of the desert. De goeij considered that the middle of the Arabian Peninsula is the first residence of Semitic race in general.

Arabian Peninsula has a great importance because of its geographical and natural location, and it is not easy to be occupied by any occupier for extension, control and influence, because the vast sands of the desert surrounds it from all sides, and it prevents the desires and policies of the occupier colonists, as it was like the stronghold of its people since the ancient time. Despite the existence of two great empires: Romans and Persians in their vicinity, their people were free in their social affairs throughout the ages.

\section{Pre-Islamic Era}

It is the pre-Islamic era in the Arabian Peninsula, and it is usually intended (a time of ignorance and lack of knowledge), and if we look carefully at the Quranic verses in which the word "ignorance" is mentioned it becomes clear to us that the meaning of "ignorance" is not that corresponds to the lack of science or the little knowledge, but it is in the meaning of foolishness, anger and selfishness. In fact, "ignorance" that is against science has been frequently mentioned in this sense in the poetry of the ancient poets, pre-Islamic poets or the modern poets alike, as mentioned in one of the seven Pendants, which is attributed to the poet Antara: "If you are ignorant of what you did not know". [3] 
The word "ignorance" is not taken in the sense, which is the opposite of knowledge or the foolishness, anger and selfishness, but it is a word that is used as a situation of the Arabs before Islam or the time period that is before Islam, and this is supported by some modern historians, as Dr. Philip says: "Even: the word "ignorance" is usually interpreted in the era of ignorance or barbarism, but in the reality it means the period in which the Arabian Peninsula was free from any law and empty from any prophet or book inspired. [4]

Shawqi Dhaif says: "The word "ignorance" is derived from the ignorance in the sense of foolishness and anger, which is apposite to the word "Islam", which denotes the reverence and obedience to God Almighty, which includes the generous congenital behavior. The word "ignorance" used in the holy Qur'an, Prophetic Hadith and pre-Islamic poetry in the sense of diet, indiscretion and anger, as in Surat Al-Baqara: "They said: Do you take us jokingly, he said: I seek refuge in God, to be among the ignorant", in Surat Al-Furqan: "If the ignorant address them, they say the peace is for you." and in Surat Al-A'rāf: "You keep yourself away from the ignorant". As well as, it is mentioned in the prophetic Hadith that the messenger said to Abu Dhar when he has reproached a man with his mother: "You are a man has ignorant character". It is mentioned in the one of the seven pendants, which is attributed to Amr b. Kulthum al-Thaghlabi:

"No one can ignore our ignorant character *** as we are in the upper class of all ignorant persons."

The word "ignorant" in all these verses is used to mean the foolishness, indiscretion and anger. The word has begun to be called the era that was near to Islam or in a more accurate sense, the era that was directly before Islam, which has all the character of paganism and morals based on diet, taking revenge and committing what was forbidden by the true religion from doing the sins." [5]

Although it is not possible to determine the period of the pre-Islamic era with a specific time, but there are different opinions of historians regarding this subject, as some of them went on to say that the era that was devoid of the messengers between Jesus and Muhammad and some of the interpreters see that what is meant by "the ignorance" in the verse: "Do not overdress like the first ignorant era", which is the time before the birth of Abraham that is known as the father of Arabs. Ibn Abbas said: It is a period between Noah and Idris. Many people considered that it was the time that was before the prophetic mission of Muhammad, as it is said by of Al-Jahiz. (Nicholson) believes that "ignorance" actually includes every period from Adam to Muhammad, [6] but it may be used in a limited circle to refer to the pre-Islamic era. Thus, it is not easy to define the pre-Islamic era with a specific time, because it is not a time connected to each other, but rather intermittent periods that occur occasionally after a while, and each period of it is a pagan sect that has its rituals, and the characteristics of its acts of worship that express the feeling of the nation according to the environmental reasons. [7]

Those who search in pre-Islamic literature do not go beyond a century and a half from the prophetic mission, but are satisfied with this era, which is the era in which Arabic language has completed its literary characteristics, and for which pre-Islamic poetry came. Al-Jahiz also notes this clearly as he said: "As for the Arabic poetry, is a new borne poetry according to its age, it is very young, the first who followed its path and made its path easy to the others was Imru al-Qais b. Hajar and Muhalhal b. Rabi'a... If we recall the poetry, we will find it - until God brought Islam - fifty and a hundred years, 
Shamsuddin, S. M., \& Ahmad, S. S. B. (2020). Ancient History of Arabian Peninsula and Semitic Arab Tribes. Advances in Social Sciences Research Journal, 7(5) 270-282.

and if we memorized two hundred years ago. [8] It is an accurate observation, because what is before this date of Arabic poetry is unknown. [9]

\section{People of Semite Arabs}

No doubt that Arabian Peninsula was the original homeland of Semites or their cradle in historical times before Islam, from which they spread to their neighboring regions and countries.

The barrenness of the island and the fertility of the surrounding countries such as Iraq, Sham, and Yemen prompted them to migrate in the form of waves that followed each other in different times separated. We summaries here what is mentioned by Shawqi Dhaif in this regard:

\section{First Semitic Wave}

The first wave that flooded from Arabian Peninsula to Iraq is the wave of Acadians: (Babylonians and the Assyrians), which emerged in the late fourth millennium BC and the early third millennium $\mathrm{BC}$. Sumerians lived for a period under their rule and influenced by their language, religion, customs, civilization and urbanization, who established their kingdom in the second half of the third millennium BC chose the city of Akkad its capital, and the most important of its kings was Sargon I (about 2350 BC) who extended its conquest to Iraq, Arabian Peninsula, and the Levant, so this was the first Semitic country known in the Middle East. Soon it collapsed, and the state of Babylon rose from its ruins and advanced in the early second millennium BC. Hammurabi was one of the most famous kings of their kingdom, who assumed power in the eighteenth century BC. We do not reach the seventh century BC until we see that the wars exhausted them, as the Medes attacked them from the Iranian plateau, and they captured their capital Nineveh, so Babylon became independent and separated from them and then a modern Babylonian state established there, which was known as the Chaldeans state (626-538 BC). Their King Bakhtnasar became well known for he destroyed Jerusalem. Soon after, Persians destroyed them under the leadership Cyrus in 538 BC. So they subjugated their state known as Persian entity state. The cycle of time circulated, then Alexander of Macedon seized the Middle East in the fourth century BC and with that, the history of Acadian's wave became ended.

\section{Second Semitic Wave}

Second Semitic wave was the wave of Canaanites that exited Arabian Peninsula heading towards the Levant and the eastern coasts of the Mediterranean Sea and established there some commercial cities, such as: Sidon, Tire, Jubail and Beirut. Greece called the people of this wave by the name of the Phoenicians. Moabites who settled in the eastern Jordan were from this wave, as well as Hebrews who settled in Palestine since the seventh century BC were from this wave. [10]

\section{Third Semitic Wave}

It is the great wave of Armenians that exited the Arabian Peninsula before BC. It is believed that they were nomadic travelers moving to the north of the desert in the Levant and Iraq, penetrating to the Gulf of Aqaba in the west and to the south of the Euphrates in the east. They were able to have an emirate between Babylon and Persian Gulf, and it was known as the Emirate of the Chaldeans who were there in the thirteenth century $\mathrm{BC}$, who were displaced to the lands of the Tigris and Euphrates in the north, and they took over Damascus, and established a kingdom there, which fought some long wars with the Phoenicians and the Hebrews, therefore, their states fell down. 


\section{Fourth and Last Semitic Wave}

It is a wave of the southern Arabs and its Ethiopian branch, which heads to the south and the coast of the Indian Ocean. The groups that landed in the Tehama of Yemen migrated to the African coast for trade. It penetrated the plateau of Abyssinia, and established a kingdom there, and a series of wars erupted between it and the southern Arabs until their state ended in the year $525 \mathrm{BC}$. Its rulers converted to Christianity since the fourth century AD. [11]

\section{Semitic Arabs}

The word "Arab" in ancient history was synonymous with "Bedouin" or (Badia). God Almighty said by the words of Joseph: "It was better for me when He brought me out of the prison and brought you from the Bedouins", (Yusuf: 100) meaning that He brought you from the Badia. People of the Badia lived in vehicles from the land of Palestine from Badia Al-Sham. God reminded them about God's grace for the Ya'qub family, as He transported them from the desert to the urban area, and the family was reunited with Egypt. The word (Arab) expressions in the (Al-Muhịt Dictionary) about the word (A'rāb) means: The residents of desert especially, and this word has no singular.

The word "Arab" is mentioned in the holy Qur'an nine times to refer to the inhabitants of the desert. But when the Arabs came and settled in the cities and towns, they used the term (urban) for the people of cities and (Bedouins) for the people of the desert. The Saba'ites to the Gregorian date, if they mentioned some of the urban tribes and their Bedouins, said: "The so-called tribe and its Bedouins". [12]

There is a big difference between the meaning of (Arab) and (A'rāb). In the opinion of Sa'd Zalām, Ibn Khaldun wronged the Arabs very unjustly in his book: (Introduction), and he did not differentiate between the meaning of the (Arab) and (A'rāb) so he described the Arabs with the ugliest descriptions, and attributed them to the most villainous characteristics, even though the the Arabs are not described by these characteristics, but rather by them the (A'rāb).

Ibn Khaldun singled out in his book: (Introduction) four chapters in succession to talk about the Arabs and the state, in which he mentioned that (the Arabs only overcome the simple peoples), and described the Arabs as brutality, looting and tampering with the corruption. As well as, (if the Arabs overpowered homelands, haste to ruin it), he mentioned that the wildness is a nature and instinct to them, and that they are not driven by a ruling rule, and that their natures are incompatible with the development, and (that the Arabs do not receive a state for them except with a religious character...). He mentioned that if religion deprived them of their souls, then their proudness will be ended and it will be easy to control them. He saw that (the Arabs are far from the state policy than the other nations) and he mentioned that one of the reasons for this (they are more Bedouin... and that their nature is taking what is in the hands of people...). [13]

Ibn Khaldun wronged the Arabs with great injustice, when he reminded them of these terrible charges, because he could not distinguish accurately between (Arab) and (A'rāb).

Now it clear that the true meaning of the word "Arab" is desert and the word "Arabia" means the desert of Arab Peninsula, Syria and the Sinai Peninsula. Greek historian Herodotus knew about the Arabian Peninsula, as his contemporary historians studied the word "Arab", and said that it is called the desert of the Arabian Peninsula in particular, as the Bedouins called the word (A'rāb). The 
Shamsuddin, S. M., \& Ahmad, S. S. B. (2020). Ancient History of Arabian Peninsula and Semitic Arab Tribes. Advances in Social Sciences Research Journal, 7(5) 270-282.

ancient historians of the pharaohs, Assyrians, and Phoenicians wanted to use the word Bedouins for the people of desert in the northern part of the Arabian Peninsula and east of the Nile Valley is the spot between the Euphrates in the east and the Nile in the west. [14] Since the ancient times, the Arabian Peninsula includes two types of population: Bedouin and Urban. The Bedouin sees in urban people a legal prey for the sake of life, it means that he had the right to struggle for the survival. Therefore, the Arab neighbors of the Greek and Roman people considered the inhabitants of the deserts in general (barbarians), i.e. brutes or they call them Saraqceni or thieves, and perhaps the word (orientalists) was derived from this last word.

The Arabs were also known as the word (taits) that Syrians launched from the people of Edessa and the inhabitants of Babylon to all Arabs, and it seems that this term is intended as a tribe for its fame in the pre-Islamic era, which was originally located in the north of Najd and then spread in the other directions. [15]

In spite of those references received from the southern Arabs in the ancient era, their history remains unclear until now, but the researchers were able to know the southern Arab civilization with its religions, gods, governmental systems, countries, and kings, and it was recognized among them that there were five kingdoms: kingdom of Maeen and Kingdom of Sheba Kingdom of Qattban, Osanian Kingdom, and Kingdom of Hadhramaut.

\section{Northern Arabs and their tribal fanaticism}

\subsection{Northern Arabs}

The northern Arabs are the Adnaniyin who lived in Hejaz and Nejd. Their clans and tribes extend to the Levant and Iraq. They have been living a desert and Bedouin living that depends more often on grazing camels and sheep, and this life did not provide them with stability as a permanent residence, except where there are some oases in Hijaz. They were carrying their homes (their tents) on their shoulders, and moving from one place to another in search of water and pasture.

All indications indicate that the northern Arabs did not congregate before B.C. in a political unity that unites them. The nature of their country was pushing them to disperse, divide, and separate. They were not guided in the meantime except by the sunrise of Islam, whose land is their first cradle. Islam united their words and combined their hearts, and made them one country. [16]

There is a difference between the Arabs of the North - including Arabs of Najd - and the Arabs of the South Arabian Peninsula as the nationality point of view. The northerners Arabs are attributed to the Mediterranean race, and the southerners are attributed to the Alpine race, also called the Hittite or Hebrew race.

There was a strong hostility between the Adnaniyin in the north and the Qahtaniyin in the south since ancient times, so that each of them adopted a slogan in the war that contradicts the slogan of the other. The difference between them remains clear despite Islam's attempt to unite the Arab nation and reunite it under its banner, and this difference has had a major impact in weakening the morality of the Arab state. [17] 


\section{2 Al-Qahtaniyyah and Al-Adnaniyyah Tribes}

Arab tribes are divided into two large parts: Adnaniyya for the northern Arabs descended from Adnan, Nizar and Mudar, and Al-Qahtaniyyah descended from Qahtan. Qahtanis migrated from the south (Yemen and Hadramout) and lived among the northern Arabs.

Who studies the history of the pre-Islamic people finds the nervousness burning among the tribes on the basis of sharing blood, and in one father or one mother. The lineages differed in the origin of some tribes, as being Adnaniya or Qahtaniya, such as Khuza'ah, Qadha'ah and Khashm, but this difference is limited. Shawqi Dhaif believes that it is true that these tribes are Qahtaniyya, and there is no doubt that many southerners or Qahtaniyans migrated due to economic and political conditions to the north, especially after the flood of El-'Uram that ruined the Ma'rib Dam. It is an undoubted constant that these migrations started from early times. Therefore, we see that the one tribe having different branches and sections in the Arabian Peninsula, as kinda tribe that migrated to the north and established a kingdom or emirate in the north of Najd, the rest of it was still residing in Hadramout when Islam emerged. The migration of these tribes is a clear indication that the migration of southerners to the north has no doubt. The tribe Tanukh migrated to Bahrain, and then settled in southern Iraq, where one of the most important of its clans (which is named Lakhm) established the Manāzira state in Al-Hira, and when the Hamadan tribes from Hadramaout migrated to the middle of Yemen between Ma'rib and Najrān, the Tayy tribe migrated to the north and settled in the mountains of Aga and Salma. The other tribes migrated to the north of Hijaz and spread in the Levant, the most important of them is the Qudha'a, Braha and Juhaynah and Bali that landed in the areas of Thamud, and Jazam, Kalb and Amilah tribes landed within the borders of Palestine, and Azra landed near Taymā' and Wādi al-Qura. Also, among those who immigrated from the south, Khuzā'a, was settled in the region of Mecca before Islam, and Bajilah came to the south of Taif. [18] As for the most important Adnaniya al-Mudhariya tribes are: Quraysh in Mecca, Thaqif in Taif, Abdul Qais in Bahrain, the Banu Hanifa in Yamāmah, Tamim and Dhabba in the desert of Dahnā', and Bakr and its many clans were spread in the area extending from the northeastern part of the island to Yamāmah and Bahrain, and the descendants returned to it Bani Hanifa, Bani Ijl, Shaibān, and Zuhal, then And more than one tribe: Bkr penetrated in the north of the island towards the east, and Banu al-Namir was near to it, while the Asad tribe descended in the north of Najd and its clans spread to Tayma', and among these Adnaniya tribes were also Kinana, Huzail, and Ghatfān and its two branches: 'Ibs And Zibyān near to Mecca.

\section{Arab Layers}

The historians divided all of the southern and northern Arabs into three layers: Arabs extinct, Original Arabs and Arabs Arabized.

\section{1. Destroyed Arab Class}

It is the class of those ancient Arab tribes whose ruins were destroyed and its news was cut off, therefore, historians did not find enough information about them except what was mentioned in the Holy Qur'an, they have found only nine Aramaic tribes from the son of Ārām b. Noah, one of them was 'Aād who resided in the land of Ahqāf, but it is not possible to determine whether the people of 'Aād were rooted from the Semitic race, from the Jeremiah dynasty or they were representing a nonSemitic culture that left culture of Iram tribe that had the buildings of high pillars? The people of 'Aād were the most brutal people who built the tall buildings indicating their civilization and urbanization, and they worshiped idols. With the passing of time, after their destruction, another 
Shamsuddin, S. M., \& Ahmad, S. S. B. (2020). Ancient History of Arabian Peninsula and Semitic Arab Tribes. Advances in Social Sciences Research Journal, 7(5) $270-282$.

people appeared, called the second people of 'Aād. Their headquarters were in Yemen, and the construction of the Ma'rib Dam is credited to their king Luqmān b. 'Aād, from whom Arab historians have told many mythical tales. Thamūd lived in the Land of the Stone and valley of al-Qura, they lived in the homes sculpted in the mountains, and their traces are still remaining in Madā'in Sālih on a week's walk from the north of Medina, including Tasm and Jadis, who resided in Bahrain and Yamāmah, and Abil al-Jahdhah between Mecca and Medina, and 'Abd Dhakhm in the city of Taif, and Wabar and Jurhum between Mecca, Medina and Taif. As for 'Amālīqa, so it is said that they are descendants of Lawd b. Sām, brother of Iram. [19]. It is said that the people of 'Aād and most of the ancient'Amāliqa are descendants of Hām. [20] It is mentioned in the Qur'an that their pride and tyranny led them to perish. Their origin is not mentioned in the Torah, and some of its interpreters have tried to apply the names of these defunct tribes to some of the names mentioned in the Torah with some artificial remarks.

Amalekites mean to the people of the North of Hijaz including the following Sinai Island, who conquered Egypt by the name of (Hyksos) and owned Babylon first and then fled from it to the Arabian Peninsula, and it is said that the word (Amalekites) was carved from the name of its tribe of its citizen in the regions of Aqaba or to the north where the Amalekites were staying. (21)

\section{2. Original Arab Class}

They are the sons of Yashjab b. Yarub b. Qahtān b. Ābir b. Shalakh b. Afkhidh b. Sām b. Noah, and it is said that Qahtān (the grandfather of the Arabs of the Southern Arab Peninsula). His son was Yāraub who is considered the first who has taken Arabic as a tongue, and his title is (Lord of eloquence).

Hence, the Arab-Qahtans were called the original Arabs. [22] They were displaced from the Euphrates Valley to Yemen, and among the most famous of their tribes are Himyar and Kahlān, and Qudhā'a was from Himyar, whose tribal branches were dispersed in the Arabian Peninsula to the areas of the Levant and Iraq, and Juzaimah al-Abrash who was from Qudhaa, had a kingdom named Tadmur in the twentieth century AD. Al-Hira and al-Anbar was under the kingdom of Juzaimah alAbrash, which was the origin of the Manazira state of al-Lakhmiyyin in al-Hira.

The sons of Ghassan were among the tribe Kahlān from Al-Azd who were the kings of the Arabs, the Levant, the Aws, and Khazraj of Medina, including also Kinda tribe of Imari Al-Qais, the pre-Islamic poet.

\section{3. Arabized Arab Class}

The houses of the Arabs Arabized were in Theāma, Najd and Hijāz to the outskirts of the Levant and Iraq, and they are called the Ismailiyyin in relation to their grandfather Ismail, and the Adnaniyyin, in relation to Adnan, one of the descendants of Ismail. They seemed to be the people of travelling resided where the water and pasture is found. Their great tribes are four: Rabia, Mudar, Iyad and Anmar, and they are the ones who made up the most of Adania tribes, Mudar had the biggest population among them then Rabia who were the children of Nazar b. Maad b. Adnan and there was a long time without any traces of the history of the Adamic. [23]

Those Arabs are called Arabized Arabs, because Ismail spoke Hebrew. When they dragged their descendants from Al-Qahtaniyya in Mecca, and they lived with Ismail who married the daughter of 
Allah granted Ismail from his wife, meaning (from the daughter of Madhadh), twelve children (male), namely: Nabit or Nabaiot, Qidar, Adabail, Mabsham, Mishma, Duma, Misha, Haddad, Yattma, Yaturd, Nafis, Qidman, and branched out of these twelve tribes, all of them inhabited in Mecca for a period of time, then these tribes spread throughout and outside the island, then their conditions were in the darkness of time, except for the children of Nabit and Qidar. The Nabataean civilization - the sons of Nabet - flourished in the northern Hijaz, where they formed a strong government that was obeyed by who were living beside them, and they took Al-Batra as their capital city. As for the children of Qidar b. Ismail continued in Mecca to procreate there, and Adnan and his son Mad were from him and Adnaniya preserved their lineage from them.

Shawqi Dhaif confirms that Arabs of the pre-Islamic era were adhering to these lineages, which is the one that composed a wide knowledge among Arabs, which is genealogy, and they are the ones who composed a wide knowledge among the Arabs, which is genealogy. Every tribe believes in their lineage and cherishes it, and that it belongs to one origin. So it is from one blood and one flesh, even they explained this relation by the meat, as expressed also their clans and branches by the stomach and thigh.

\section{Tribal System in Pre-Islamic Era}

\section{1. Integration and alliance among the tribes}

Arab tribes were united in their tribal systems that were based on the tribe and the participation of its children in one origin and one homeland, which was a mobile home with the pastures, as well as their participation in the traditions and customs was adhered by them tightly, and the close relationship that linked the members of the tribe was the tribal nervousness, and pre-Islamic poetry is full with the tribal nervousness, but we rarely find in it that the Arab prides himself on the other nations. [25]

Arab tribes did not have a clear feeling of the Arab race or the Arab nation, although there was a little feeling of unity, not only between the northern tribes, but between them and the southern tribes, so the Arab tribes did not gather under one banner, but they had all was a tribal union had a president, and among the federations that were gathering the tribes were the Alliance Associations. It is believed that these unions played a big role in forming the tribes, as the weak clans were joined to the strong and powerful clans to protect them and respond to the aggression against them, and in the case that the tribes entered into an alliance, they had all their rights over their allies. Some tribes were separated from one alliance to another to achieve their interests. A few tribes did not enter into the alliances, so they were named Jamarat al-Arab (Herd of Arab). The allied tribes were dreadful to touch them. The word alliance in Arabic is originally used in the sense of oath that they were swearing in their covenants, as they usually were dipping their hands during the holding of their alliances in the things had good smell or in the blood and they were saying: The blood is blood and demolition is demolition... and sometimes they set fire to their alliance, and one of the wellknown alliances in Mecca was "Alliance of the people had good behavior". Under this Alliance the sons of Abd Manaf, the sons of Zahra, the sons of Tmim, and the sons of Asad had contracted against the sons of Abd al-Dār and their allies, so they dipped their hands in a pot was full of a good smelling 
Shamsuddin, S. M., \& Ahmad, S. S. B. (2020). Ancient History of Arabian Peninsula and Semitic Arab Tribes. Advances in Social Sciences Research Journal, 7(5) 270-282.

thing. The most honorable of them was the alliance of curiosity, and in it the tribes of Quraysh allied to lift the grievance against every oppressed in Mecca, and to support and help him.

\section{2. Tribal Senate or Parliament}

These allied and non-allied tribes had a council (the Senate) that included the seniors of clan that was their symposium, in which they looked at the affairs of the tribal society, and the session was open to everyone who could attend and speak, and its convening did not have a specific date. They meeting usually was in the evening, and whenever they had a lot of issues need to be discussed, they discuss and debate, and in the meantime their masters declare their judgments and experiences in the life. The decisions and recommendations of these councils were effective, as all tribesmen complied with them and did not deviate from them.

\section{3. Tribes and sovereignty over the tribes}

Usually the master of tribe was a senior sheikh who had a long experience, skill, wisdom, reasonable opinion and expanded wealth. Who can lead the tribe in the war and fighting, divide its spoils, receive the delegations of the other tribes, held peace and alliances, and held hospitality, but it should not be understood that he had a broad sovereignty, as his sovereignty was symbolic. The master in the tribe was the brightest person who had a long experience and often had inherited his sovereignty from his fathers to achieve a high heretical status. He had no rights except that he must be respected by everyone. As for his duties, he had many duties. He must have courage, generosity, relief to help the others, and care taker of the neighborhood, and helper of the destitute and the weak. He must be responsible the largest portion of the tribe's mistakes paying the money for their penalties. He must be a tolerant to forgive the others. [26] One of the most important things in his personality was that he was doing for the social welfare between the tribes, if they had any serious problem they had to get help from their sheikhs and the noble persons, and they must take their advices, and the master must listen to all, as they all had equal rights. One of the most important indications of this equality was the teasing system, which was for the right to settle in the tribe. If someone hires someone, he becomes a tribe bound by the rights.

He has to perform his duties like the other members of the tribe.

\section{4. Members of the tribes and their duties towards their tribal society}

All members of the tribe put themselves to serve the tribe and its rights, and on top of the rights is the right to take revenge, so every individual in the tribe sacrifices for the tribe by himself and his money, it is his life and his entity, and he is proud of his individuality, personality and freedom living within its framework, driven by that with great nervousness controlled their souls. They were sanctifying nervousness, which was greater than sanctifying the religious ceremonies that were shared by the other tribes. As for the tribal ceremonies, they were specific to the tribe and its sons who were united by the one blood and one lineage. Perhaps one of them tolerated his religion, as the religion was not interested in many cases. As for the nervousness, he could not forgive any of its duties. The tribe, for its part, was giving its children the same rights, as it was supports them in the misfortunes that inflict upon them unjust or oppressed, and the proverb is known to them: (Support your brother, unjust or wronged), and because of their sit-down on the pastures and their consideration that the war is as a means of the life survival, they have turned into a kind of military battalion. Every tribe is always ready for the war, executioner, and raiding of the surrounding Bedouins and urbanites, and therefore Clement Huart sees: "All Arabs - urban or Bedouin - were born men of war". [27] It is always complaining about weapons until it protects its reserves, homes, 
wells and pastures. Therefore, the courage was the best ideal to them. They were always proud of their heroism and the number of those who were killed by them in their wars. They were assaulting their Yemeni and Indian swords with their spears, bows, shields, gears, knives, and helmets, as well as their horses, they praised their horses to pay tribute to the horses, and renamed the horses with many names. [28]

\section{Conclusion}

We extract some facts from all that we have mentioned in the Arab tribes and their tribal units that made up the pre-Islamic Arab society:

- The pre-Islamic Arab community in general was a tribal society, and its tribal social unit was consisting of the extended family.

- The tribe was headed by an experienced sheikh who was distinguished by the wisdom, good opinion and wealth, and he was the one who led it in the wars, separated them in the disputes and quarrels, received delegations behalf of the tribe, held the conciliation and alliances on their behalf, and carried the largest portion of their crimes and penalties, performed most of their duties, and in exchange for all of that, he had the right to be obeyed and respected.

- The people of the tribe believed in their unity and fanaticism, and they showed solidarity with each other in what one of them earns, as the Arab proverb says: "The clan involves in the crime".

- If the individual went out on the unity of the tribe, acted unilaterally, committed a crime in the tribe or committed what it can disgrace the tribe or drag it on its stigma or his crimes multiplied outside the tribe until the tribe was unable to support him or bear his consequences, then the tribe would make him out and withdraw from him the right to belong to it, and disavowed it, so it was called (Deposed).

- Pre-Islamic community consisted of three social classes:

A. Class of the Liberals, they are the sons of the tribe who belong to the one father, and in their veins, pure Arab blood is flawless.

B. Class of loyalists, they are the emancipated from the slave or free slaves who were deposed by the tribe, and took refuge in another tribe to live in their shroud and protection.

C. Class of slaves, they are the prisoners who fall into the hands of the tribe at its wars or the slave brought from foreign countries, especially Abyssinia. The worst of all these classes was the slave class, and it was the fastest of the classes responding to the call of Islam as the best system - social justice in the world of mankind -. 
Shamsuddin, S. M., \& Ahmad, S. S. B. (2020). Ancient History of Arabian Peninsula and Semitic Arab Tribes. Advances in Social Sciences Research Journal, 7(5) $270-282$.

\section{References}

[1] Shawqi Dhaif. Pre-Islamic Era / p. 17, and the general Islamic history / Ali Ibrahim Hassan p. 23

[2] General Islamic History / Ali Ibrahim Hassan, Egyptian Renaissance Library, p. 24/25

[3] Ibid. p. 27.

[4] Hitti ph: History of the Arabs, p. 37

[5] Shawqi Dhaif. Pre-Islamic Era p. 39

[6] Nicholson: Literary History of Arabs p.30

[7] Muhammad Abdul Mu'īd Khan: Arab Myths Before Islam, p. 3, and General Islamic History, P. Ali Ibrahim Hassan, p. 29

[8] Al-Jahiz. Animal. Cairo: Al-Halabi Edition Part. 1, p. 274,

[9] Pre-Islamic Era, .p 38

[10] Sa'd Zalām: From the technical phenomena in the pre-Islamic poetry, Dār Al-Manār for printing, publishing and distribution, Cairo, 1992, p. 23

[11] Shawqi Dhaif. The Pre-Islamic Era, pp. 25-26

[12] Jurji Zaidān: The Arabs before Islam, pp. 41-42

[13] Ibn Khaldūn. Introduction, Dār Al-Bāz Press - Makkah Al-Mukarramah, pp. 149-152

[14] Jurji Zaidan: Arabs before Islam, Cairo, 1922 AD, p. 31

[15] Noldeke: history of the world, vol. 8 p. 4 Abdul Mun'im Majīd. Political History of the Arab State, pp. 46-47

[16] Pre-Islamic Era, p. 30

[17] Ali Ibrahim Hassan: General Islamic History, p. 35

[18] Pre-Islamic Era, p. 56

[19] Jurji Zaidān: Arabs before Islam, p. 37

[20] Ali Ibrahim Hassan. General Islamic History. Egyptian Renaissance Library, Cairo - 1971, p. 32

[21] Jurji Zaidān. Arabs before Islam, p. 38

[22] Ali Ibrahim Hassan, General Islamic History, p. 34

[23] Tahir Abdul Latif Awad, Arabic literature: p. 44

[24] Ali Ibrahim Hassan, General Islamic History, p. 34

[25] Ahmad Amin Ḍuha al-Islam Part 1, p. 171

[26] Pre-Islamic Era, pp. 59-60

(27) Clement Huart; journal Asiatique, 1913 p.216

[28] Pre-Islamic Era, p. 61-62 